\title{
Latife Tekin ile Cengiz Aytmatov'un Romanlarında Geleneğin Kurgusal İşlevi ve Metinlerarasılık Bağlamında Bir Çalışma
}

YASIN YAVUZ*

\begin{abstract}
Öz
Bir sanat/edebiyat akımı olarak postmodernizm Türk edebiyatında ilk defa 70'li yıllarda görülmüş ve 80'li yıllarda birçok yazar tarafından bilinçli olarak bu türde eserler verilmiştir. $\mathrm{Bu}$ akımın en önemli tekniklerinden birisi olan metinlerarasılık, geleneğin kullanımına kapı aralamıştır. Latife Tekin ve Cengiz Aytmatov da bu aralığı değerlendirip eserleriyle destan, masal ve halk hikâyeleri gibi geleneksel anlatılar arasında bağ kurmuş ve bu bağı işlevselleştirmişlerdir. Bu çalışmada, ortak kültürden esinlenerek Ak-Köbök destanı ve ad koyma motifi gibi geleneksel anlatıların kendisinin ya da onları çağrıştıran motiflerin Latife Tekin ve Cengiz Aytmatov tarafından nasıl işlevselleştirildiğinin üzerinde durulmuş, her iki yazarın da metinlerinde kullandığı motiflerin tespiti yapılmıştır.
\end{abstract}

Anahtar sözcükler: Latife Tekin, Cengiz Aytmatov, gelenek, postmodernizm, metinlerarasılık, Ak-Köbök, roman.

\section{THE FICTIONAL FUNCTION OF TRADITION IN THE NOVELS OF LATİFE TEKIN AND CHINGHIZ AITMATOV AND A STUDY IN THE CONTEXT OF INTERTEXTUALITY}

\begin{abstract}
As a movement of art/literature, postmodernism has firstly shown up in 70s in Turkish Literature; and in 80s, many writers has consciously produced their works in the context of postmodernism. Intertextuality, one of the key techniques of this movement, paved the way for using tradition. Latife Tekin and Chinghiz Aitmatov has also used this technique and established a bond among traditional narratives such as epics, fables, folk stories and functionalized it in their works. In this study, the traces of Ak-Köbök legend and "the motif of naming" itself or its connotations were scrutinized in the texts of Tekin and Aitmatov. In
\end{abstract}


brief, in the article, the traces of traditional narratives and oral culture were firstly detected and after analyzed in both writers' novels.

Keywords: Latife Tekin, Chinghiz Aitmatov, tradition, postmodernism, intertextuality, Ak-Köbök, novel.

\section{Giriş}

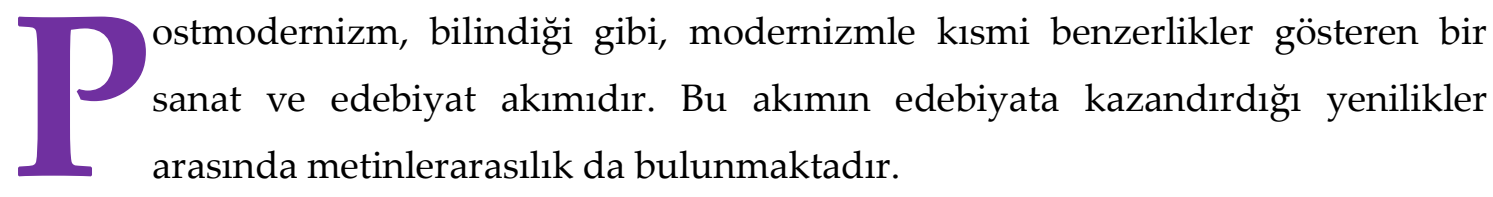

Metinlerarasılık genel anlamiyla bir yeniden yazma işlemi olarak da algılanabilir (Aktulum 2011: 452) Roman ve hikâye gibi modern anlatılara ya da masal ve söylence gibi geleneksel anlatılara ait parçalar bir yazar tarafından kendi metninde yeniden yazılabilir.

Metinlerarasılığın birçok yöntemi vardır. Bunlara örnek olarak pastiş, kolaj, palempsest ve parodi verilebilir. "Bir metinlerarasılık/yeniden yazma yöntemi olarak 'anıştırma' ise bir metne, bir düşünceye, bir şeye doğrudan belirtmeden sezdirim yoluyla gönderme yapılmasıdır." (Aktulum 2011: 419) Alıntılama yapan yazar, alıntıyı bilinçli olarak ve kapalı bir şekilde yapar. Bu teknik, dayatmayla, yani işlevsel olmayacak şekilde kullanılmaz. Anıştırma yöntemi ancak işlevsel

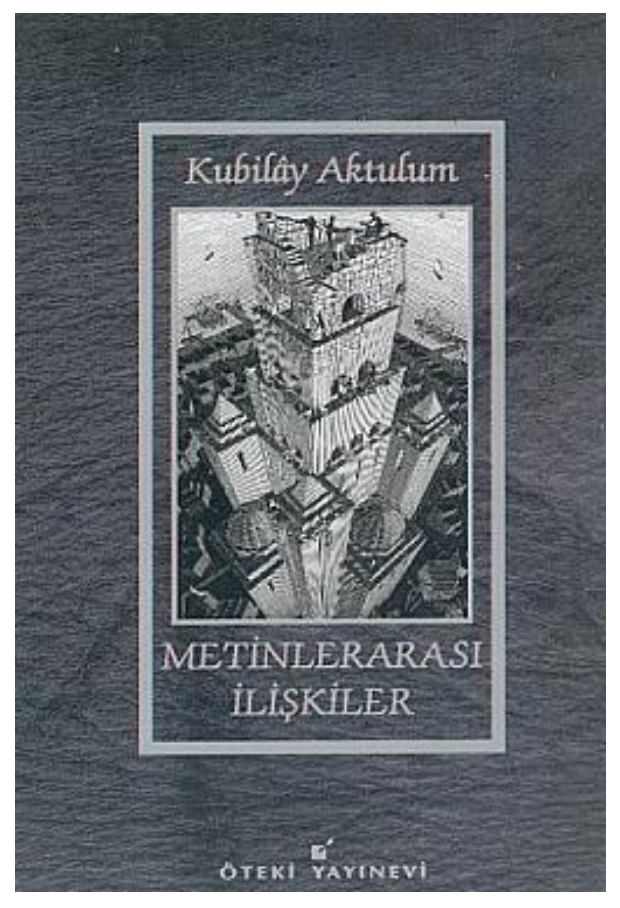
olduğu zaman başarılı bir sonuç verir.

Anıştırma yönteminde önemli olan diğer bir konu ise göndergeye oldukça yakın olmasıdır. Kubilay Aktulum'un yazınsal sözcükleri tanımlayan Dictionary of World Literary Term'den aktardığı şu pasaj, anıştırma ve gönderge arasındaki farkı açıklar niteliktedir: “Bir şeyi doğrudan anmadan belirtme. Doğrudan anma bir göndergedir. Anıştırma, bir sözcüğün alıntılanması ya da bir başka yapıtın, kimliği söylenmeden ya da açıç̧a bildirilmeden anılmasidir." (Aktulum 2000: 109)

Metinlerarasılık/yeniden yazmanın bir yöntemi olan anıştırmanın, postmodern edebiyatta yeni bir üslup denemesi için alan yarattığı görülmektedir. Latife Tekin ve Cengiz Aytmatov'un bilinçli olarak bu tekniği kullanıp eserlerinde bir başka anlatıların izlerini barındırmışlardır. Her iki yazar da geleneği anlatılarında hareket noktası olarak belirlemişlerdir. Özellikle Aytmatov'da bu durum kimlik hâlini almış, hemen her eserinde görülmüştür. Onun romanlarında masal, söylence ve destan gibi geleneksel anlatıların 
izlerini görüyoruz. Bu izler, aslını yitirmez, onu anıştırır ve kurguda işlevseldir. Aynı kullanım Latife Tekin'de de vardır. Özellikle ilk romanı Sevgili Arsız Ölüm'de (1985) anıştırma yöntemi ile geleneği işlevselleştirmiştir. Onların eserlerinde gelenek, postmodernist anlatıların altındaki asıl kaynaktır.

Bu çalışmada bu izleri tespit edip, kurmacanın bir unsuru olarak hangi işleve sahip olduğunu göreceğiz.

\section{Modern Zamanın Masal Anlatıcısı: Latife Tekin}

1983 yılında yayımladı̆̆ Sevgili Arsız Ölüm adlı romanıyla yakaladı̆̆ şiirsel/masalsı dili ve geleneksel anlatılara olan bağlılı̆̆ını koruduğu özgün biçemi ve içeriğiyle kendisinden söz ettiren Latife Tekin, 80 sonrası Türk romanında önemli yeniliklere imza atan birkaç yazardan birisidir. Tekin, daha ilk romanıyla "alışılmış roman tekniklerinden yakasını sıyırmış" (Moran 2015: 77) yeni bir anlatım biçimi ve tekniği geliştirmiştir. “Tekin, bu romanda, o güne kadar daha çok gerçekçi tarzda anlatılmış olan

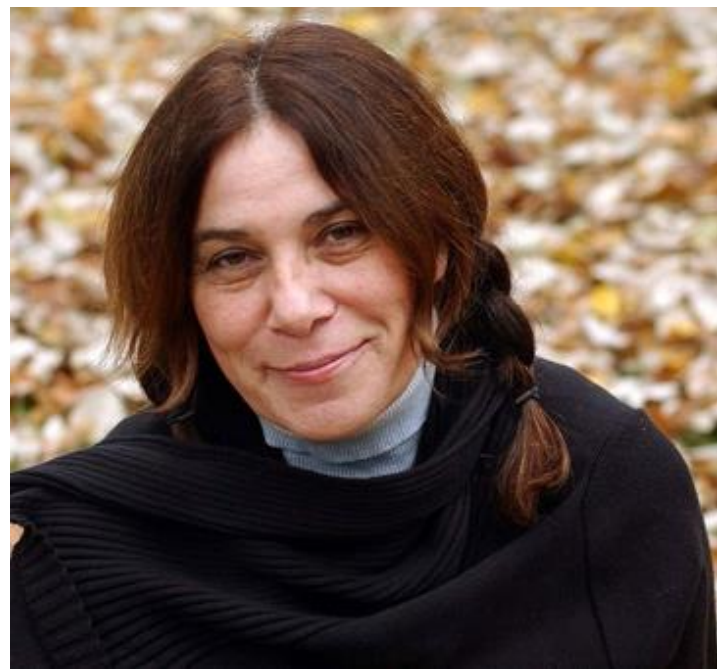

Latife Tekin köylerdeki ve varoşlardaki yaşamı, büyülü gerçekçi bir bakış açısıyla anlatmıştır."(Öktemgil 2003: 37) Latife Tekin'in büyülü gerçekçiliği, fantastik yolculuğu, Nazlı Eray'dan farklı olarak, Türk dünyası destanları, "Anadolu'da hâlen daha yaşamakta olan batıl inanış ve hurafeler gibi yerli kaynakları" (Balık 2011: 26) romanlarında işlevselleştirmesinden geçmektedir. "Romandaki fantastik olaylar kâh gerçekten olmuş gibi kurmaca dünyanın bir parçası olarak sunuluyor bize, kâh kişilerin boş inançları olarak." (2015: 89) Ancak her iki durumda da ya karakteri tamamlayan bir motif ya da kurguyu ileri taşıyan bir olay halkası olarak fantastik/geleneksel anlatım işlevselleşmektedir. Latife Tekin'le birlikte “[d]estanları/mitleri/masallarıyla bir fantastik kurmaca cenneti olan Türkiye, yıllarca dışladığı fantastik öğeye edebiyatında yeniden yer açıyordur." (Ecevit 2013: 30)

Latife Tekin Sevgili Arsız Ölüm'den sonra da "toplum" ve "yoksulluk" izleklerinden kopmayarak bellek ve arayışın öykülerini anlattığı politik romanlarıyla dikkat çeker.

Latife Tekin'in romanlarında özellikle yoksulluk izleği ön plana çıkmaktadır. Yazar, Yıldız Ecevit'in deyimiyle "ülkenin kültüründe zamanla belirleyici bir rol oynamaya başlayacak olan kırsal kökenli varoş insanını edebiyat düzlemine taşır" (2013: 21) Böylece, taşıdığı düzlemde, sözcüklerle izlerini sürdüğü, bulup var ettiği yoksulların savunucusu olur. Her romanda yoksulluğun farklı bir yönünü, farklı bir boyutunu ele alır. 
Fantastik ögeleri çağdaş teknikle birleştirerek özgün izlekleri çarpıcı bir biçimde anlatan Tekin'de roman tanımı da oldukça farklıdır. Yazar, Hasan Ali Toptaş ile yaptığı bir röportajda "Ben aslında Türkçede çok az roman yazıldığına inanıyorum.” (Toptaş 2015: 35) der. Bu söylemin anlatıbilimsel açıklamasını ise "kurgu [ve] [...] olması gereken dramatik dönüşüm[lerin]" (2015: 35) yoksunluğu ile yapar. Tekin'in ifade ettiği şey, Batı'da tanımı yapılandan farklı olarak kopuk, şiirsel ve büyülü/fantastik bir metni yazıyor olmasıdır.

Burada baskın gelen ve yazarın bu kanıya varmasında etkili olan asıl etken ise dildir. Tekin, yine aynı röportajda "daha çok masalımsı, destanımsı tuhaf şeyler yazıyoruz." (2015: 35) diyerek dilin romandaki -en azından kendi romanındaki- yerini ve gücünü ifade eder. Bu yapı, özünde, Tekin'in yeni söylem arayışlarında ulaştı̆̆ı uç nokta, özgün biçim ve baş döndüren dil kavgasından başka bir şey değildir. Bu eserlerin her biri Tekin'in doğa, birey, politika, yoksulluk, göç vb. sosyolojik izlekleri bünyesinde barındıran, çok yönlü külliyatını oluşturmaktadır.

Öte yandan evrensel değerleri gelenekle harmanlayarak anlatması bakımından Tekin'le paralel bir anlatıma sahip olan Cengiz Aytmatov'u ele aldığımızda her iki yazar arasındaki benzerlik net bir şekilde açığa çıkacaktır.

\section{Cengiz Aytmatov'un Yüksek Felsefesi ve Roman Geleneği}

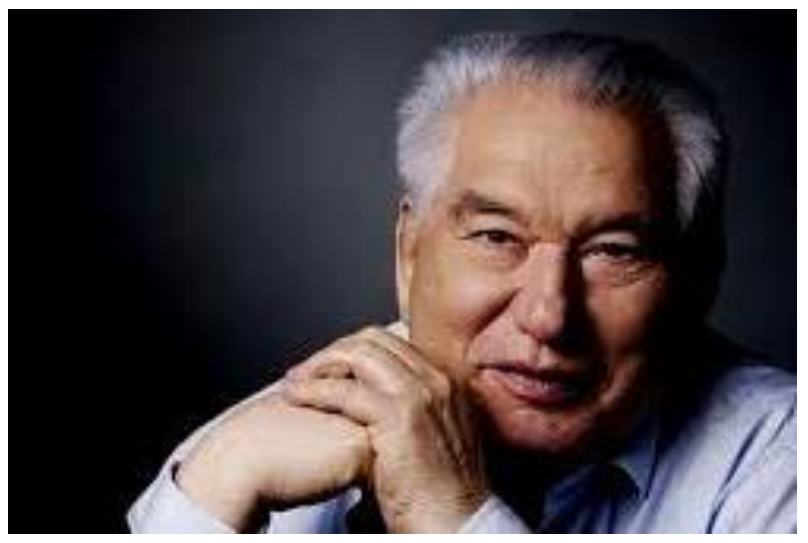

Cengiz Aytmatov

Kırgız edebiyatı, kültürü ve diplomasisi için önemli işler yapan Cengiz Aytmatov Kırgızlar için oldukça değerli bir isimdir. Fakat Aymatov, romanlarında yalnızca Kırgız halkının değil, bütün insanlığın, doğanın sorunlarını anlatır ve bu sorunlara çözüm önerisi sunar. Bu nedenle onun eserleri bütün insanlığa açık bir çağrı niteliği taşımaktadır. Aytmatov'un eserleri,

bütün insanlığın ortak sorunu olan savaşı ve onun insanlara verdiği zararı anlatır. Ayrıca Aytmatov, insanların doğanın dengesini bozmasına, uyuşturucu kaçakçllı̆̆ına, dinde söylem özgürlüğüne, iyi/kötü çarpışmasına da değinir ve bunları eleştirir. Bütün bu izlekler, Aytmatov'un yüksek felsefenin örnekleridir.

Aytmatov'un önemli eserlerinden olan Beyaz Gemi'de (2016) ana karakter olan "çocuk", yeryüzünde ne kadar üzgün, itilmiş ve yitik çocuk varsa onu temsil etmektedir. Dişi Kurdun Rüyaları'nın (2016) ana karakteri Abdias iyiliği temsil etse de bu yönüyle çok tutunamaz ve kötüler tarafından vahşice öldürülür. Kassandra Damgası 'nda (2013) Robert Bork'un ölümü ise yeryüzündeki kötülüklerin artması nedeniyle doğmak istemeyen balinaları haklı çıkarır; 
bu olay, iyiliğin ve ahlakın yokluğuna işaret eder. Hatta Kassandra Damgası'nda Aytmatov, Filofey'in mektubu aracılığıyla insanların kötülüklerini şöyle sıralar: "Açlık, varoşlar, hastalıklar ve bunların içinde AIDS, savaşlar, ekonomik krizler, sosyal patlamalar, cinayetler, fuhuş, uyuşturucu bağımlılığı ve uyuşturucu mafyası, etnik çatışmalar, ırkçılık, ekolojik ve enerjik felaketler, denemeler, kara delikler vs. Bunlar yapay, insanoğlunun kendi ürünü."(2013: 42-43)

Aytmatov'un romanları ve romanlarında ele aldığı konular, tartıştığı, eleştirdiği her şey insanlığın daha temiz, adaletli, iyi ve özgür olması adına sessizce atılmış büyük bir çı̆̆lık, derin bir yakınma biçimidir.

Aytmatov'un biçeminin en belirgin yönü eserlerindeki psikolojik tahlillerdir. Romanlarındaki her karakterin davranışı, düşünce tarzı ve sınıfsal konumu arasında bir bağ vardır. Aytmatov karakterlerin psikolojisine yönelerek onların düşünce yapısını şeffaf bir örtüyle okuyucuya sunar. Ancak bu, Aytmatov'un sadece psikolojiye eğildiği anlamına gelmemektedir. Onun romanlarında olay örgüsü ve mekân da oldukça önemli bir unsurdur. Sözgelimi Beyaz Gemi adlı romanında mekân, bir fondur. Karakteri tamamlayan yardımcı öge görevi görüyordur. Romanda olay Isık-Göl civarındaki San-Taş vadisinde geçer ve burası çocuğu tamamlayan bir öge görevi görmektedir.

Aytmatov'da olay örgüsü ise özellikle Dişi Kurdun Rüyalarl, Gün Olur Asra Bedel (2016) ve Kassandra Damgası gibi romanlarında oldukça iyi kurulmuş girift, sağlam, sarkmayan yapısıyla baş döndürecek düzeydedir.

Aytmatov'un romanlarında öne çıkan diğer önemli yan ise söylem ve dildir. Yazar, masalsı bir anlatıma sahiptir. Bu, kimi zaman o kadar yükselir ki, okur, sıradan kurmaca bir metin mi yoksa söylem gücü yüksek bir masal/destan mı okuyor, tam anlayamaz ve ikileme düşer. Beyaz Gemi’den aldığım pasaj konuyu daha açık kılacaktır: “Az gittiler, uz gittiler, bir yaz, kış, bahar ve sonbahar, yine bir yaz, kış, bahar ve sonbahar, sonra yine bir kış, yaz, bahar ve sonbahar... insan ayağı değmemiş ormanlardan, kızgın çöllerden, ayak batan kumlardan, yüksek dağlardan, çağıl çağıl ırmaklardan geçtiler" (2016: 62) Aytmatov yukarıda pastişe bir örnek vermiştir. Yinelemelerle yakalanan şiirsellik, düşsel yolculukla desteklenerek yücelmiş ve füsunkârlaşmıştır.

Yalnızca bir yazar olmayan Aytmatov, aynı zamanda iyi bir gazeteci, zeki bir siyasetçi, güçlü ve çağcıl bir Manasçı'dır. O, evrensel romanlarının yanında mahalli söylemleri olan, köklerine, atasına bağlı, Kırgızlar için büyük bir simgedir. Aytmatov, sadece Kırgız Türklerince değil, tüm Türk dünyası tarafından sevilen ve okunan bir yazardır. Onun eserleri, Türk ortak yazınının kıymetli mirasları arasında yer alır. 


\section{Latife Tekin ve Cengiz Aytmatov'da Geleneğin Kurgusallaşması ve Postmodernizm}

Latife Tekin postmodern bir teknik olan anıştırma yöntemiyle geleneği romanlarında işlevselleştirir. Bu o kadar ince bir şekilde yapılır ki, okur, bunu bir teknik olarak değil de, romanın gereği, bir parçası olarak görür. Ayrıca Tekin'de zaman kullanımı da geleneksel roman anlatımının dişındadır. Latife Tekin "zamanı ve mekânı bulanık bırakmayı yeğler [...] Geçen zamanı okur olaylardan çıkartmak zorundadır." (2015: 79) Bu da onun postmodern yönünün bir başka örneğidir.

Genel bir çizgiyle motif/içerik bağlamında geleneğin izleri, teknik/biçim bağlamında ise postmodern anlatımın izleri görülür Latife Tekin'in romanında. Diğer taraftan, gelenekten beslenmesi ve bu kaynağı metninde kullanması bakımından, Latife Tekin'le benzer bir çizgide metinler üretmiştir.

Cengiz Aytmatov üzerine pek çok değerlendirme olmasına karşın postmodern yönü görmezden gelinmiş, hemen hemen hiç konuşulmamıştır. Hatta Aytmatov'da kendisiyle yapılan bir söyleşide postmodern edebiyatı kabul etmediğini ifade etmektedir. Her şeye rağmen o, postmodern bir yazardır. Romanlarında "birden fazla edebî türü aynı eser içinde kullanması," (Bayraktar vd. 2013: 162) anıştırma yöntemiyle metinlerarası ilişki kurması, üstkurgu ve postmodernizmin birçok tekniğini kullanması onun postmodern bir yazar olduğunu göstermektedir.

Aytmatov da Tekin gibi zamanı ve mekânı bulanık bırakır. Sözgelimi Beyaz Gemi'de zaman hakkında net bir çıkarım yapmak mümkün değildir. Biz romanın Nine'nin çocuğunu savaşta kaybetmesinden hareketle II. Dünya Savaşı sonrasında yazıldığını anlıyorsak da kesin bir tarih veremiyoruz.

Her iki yazar da eserleriyle Türk dünyası destanları arasında metinlerarası ilişiler kurmaktadırlar. Bu ilişki, geleneğin yeni metnin oluşmasında kurgusal bir işleve sahip olması sebebiyle oldukça önemlidir. Tekin ve Aytmatov kullandıkları geleneksel miti, kendi kurmacalarında sokması, onu metne yayması, geleneksel metnin orijinal hâline zarar vermemekle birlikte farklı bir okuma alanı oluşturmaktadırlar.

Bu doğrultuda, gerek çoğulcu yapısı, gerek öze bağlılık gerekse postmodern teknikleri kullanımı bakımından her iki yazar da aynı roman geleneğine sahiptir. $\mathrm{Bu}$ nedenle yazarların eserlerinde geleneğin kurgudaki işlevini tespit

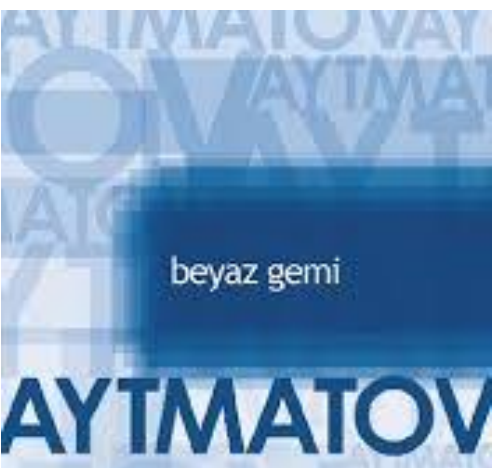
ederken bu açıdan bakılması, tespiti kolaylaştıracağı gibi, doğruluk payını da arttıracaktır. 


\section{Ak-Köbök (Ak-Köpük) Destanı}

Türk destanlarında görülen mitolojik doğumlardan bir tanesi de Ak-Köbök'ün doğumudur. Bu destanın “Kuzey Türkleri tarafından çeşitli varyantları söylenir.”(Ögel 1995: 4) Destanda Ak-Köbök normal doğumu reddeder ve annesinin karnını yırtarak doğmak ister. Annesi bu duruma karşı gelir ve onun Tanrının buyurduğu yolla doğmasını ister. $\mathrm{O}$ zaman Ak-Köbök de normal doğumu kabul eder ve doğduktan hemen sonra babasının kılıcını alıp balık tutmaya gider. Latife Tekin ve Cengiz Aytmatov, destandaki “vaktinden önce konuşma" ögesini romanlarında kullanarak işlevselleştirmiştir.

Vaktinden önce konuşma öğesinin destandaki örneği şöyledir:

“... Ak-Köbök'ün doğma zamanı gelmiştir. Herkes toplandı. Ak-Köbök, annesinin karnında, şöyle söylenip durdu:

'- Ben bu yolla doğmayacağım! Ben annemin karnını yırtarak doğacağım!'”' (1995: 4)

Latife Tekin'in Sevgili Arsız Ölüm adlı romanında yeniden yazma örneği olarak AkKöbök'e, romanın başat karakterlerinden olan Dirmit'in doğmadan önce anasının karnında konuşmasıyla rastlarız: “... Ama işin aslı başkaydı. Doğan kız, anasının karnındayken iki kez üst üste, hem de Atiye'nin anasının sesiyle 'Ana! Ana!' diye çağırdıydı." (1985: 15)

Tekin'in ana karakterlerinden biri olan Dirmit, tıpkı Ak-Köbök gibi henüz doğmadan konuşmuştur. Bu konuşmayla Dirmit romana dâhil olur ve Latife Tekin de romanın geneline hâkim olan büyülü anlatımın bir örneğini sergiler. Bu bölümün roman açısından en önemli işlevi Dirmit romana girmesi ve romanın ilerleyen bölümlerinde başından geçecek olan büyülü/masalsı olayların, mitolojik doğumla, daha mümkün kılınmasıdır.

Cengiz Aytmatov'da Ak-Köbök'ün kullanımı oldukça farklıdır. Kassandra Damgası'nda yazarın sözünü emanet ettiği karakter olan Filofey'in Roma Papası'na yazdığı mektubun son kısmında sözü “Kassandra embriyoları”na bırakır. Embriyolar şöyle seslenir insanlığa: “Ben, Kassandra embriyosu! Şimdilik benimle vedalaşmak için henüz geç değil ve ben de buna hazırım. Ben, Kassandra embriyosu; birkaç gün kendimi hatırlatacak, size sinyaller göndereceğim. Ben, Kassandra embriyosu; doğmak istemiyorum, istemiyorum, istemiyorum... Ben, Kassandra embriyosu!"' (2013: 24)

Yukarıda alıntılanan pasajda Aymatov, Kassandra Damgası adlı romanın temel izleğini içinde barındırır: Kötülük! Aytmatov bu romanında kötülüğün kaynağına erişmiş, bunun nedenleri ve sonuçlarını ifade etmiştir. Bu sonuçlar neticesinde Kassandra embriyosu "gelecekte [onu] bekleyen felaketlerin ve acıların" endişesiyle doğmak istemez. Bu felaket ve acıların hiçbiri Tanrı yazgısı değildir, tamamı insanoğlunun marifeti sonucu ortaya çıkmıştır.

Embriyoların konuşması hem romandaki ana izlek olan kötülüğe karşı duruş hem de romanın içinde oluşan kaosun temel nedenidir. Romanın kötü kahramanlarından olan 
Ordok'un başkanlık seçiminden Robert Bork'un makalesine kadar birçok yerde etkili olan bu olay romanın hareket noktasıdır. Olayları başlatan ve ileriye taşıyan önemli bir halkadır.

Ak-Köbök mitolojisi birbirinden bağımsız iki yazarda iki farklı şekilde tezahür etmiştir. Tekin'de “doğmak isteyen" karakter kurguya katılmış; Aytmatov'da ise "doğmak istemeyen" embriyo romana yön vermiştir.

\section{Mahlas Verme Geleneği}

Mahlas verme Türk destanlarında yaptıkları bir işle alakalı olarak gerçekleşmektedir. Oğuz Kağan Destanı'nda Oğuz Kağan'ın çok sevdiği aygırı kaybolur ve bir er dağlara girer, dokuz gün sonra aygırı yakalayıp çıkar. Dağlar erin girdiği gibi hâlâ karlıdır. Oğuz Kağan aygırı görünce çok sevinir ve bu ere "Karluk” adını verir: “ Dedi: 'Baş ol Beğlere, sen de artık burada kal! Sana 'Karluk' diyeyim, ölmeyen adını al!” (Ögel 1993: 121-124)

Mahlas verme geleneği Dede Korkut Hikâyeleri'nde de çıkar karşımıza. Sözgelimi Dirse Han'ın oğluna mahlas verme işini Dede Korkut yapar. Bayındır Han'ın ak meydanında cenk edip, bir boğayı öldürdüğü için Dede Korkut "Boğaç” adını verir. Özetle Türk mitolojisinde kişilere ekseriyetle kahramanlıkları doğrultusunda ad verilir, mahlas takılır.

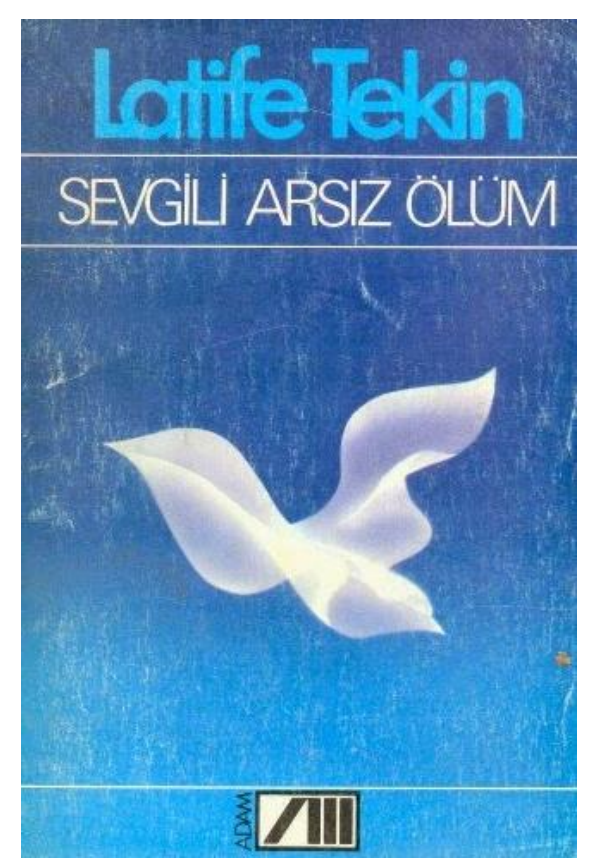

Sevgili Arsız Ölüm'de on beş adlandırma yapılır"(Arık 2007: 165) Tekin'in kahramanları da tıpkı Türk mitolojisinde olduğu gibi yaptıkları kahramanlıkları ya da roman içerisinde yaptıkları eylemler dolayısıyla ad alır. Bu motiflerin romanın kurgusundaki işlevini şöyle açıklayabiliriz: Karakterler yaptıkları eylemler nedeniyle aldıkları ad, onları o eylemle bütünleştirir ve okur karakterin o özelliğini belleğinin bir yerine kazır. Sözgelimi romanın bir yerinde Ali'ye Kore'ye gittiği için “Koreli" denir. (1985: 32) Bu okurun belleğinde yer edinir ve bu gerçek hiçbir zaman değişmez; okur, Ali'nin Kore'ye gittiğini aklının bir köşesine yazar. Mahlas verme işlemiyle aynı zamanda karakterin bir özelliği okura belletilir. Ayrıca bu adlandırmalar kalıcı değildir. Bu da karakterlerin roman boyunca aynı davranışı göstermediğini, kendi kader ve devinimleri olduğunu göstermektedir.

“Türk destanlarından özellikle Oğuz Kağan Destanı'nda dikkat çeken şahıslara mahlas verme, Sevgili Arsız Ölüm ve Berci Kristin Çöp Masalları'nda ağırlıklı olarak kullanılır. [...] Sevgili Arsız Ölüm'de otuz civarı lâkap kullanan Tekin, ikinci romanında da benzer bir tasarrufta bulunur." (2007: 171) 
Aytmatov'da bu motife Beyaz Gemi romanında denk geliriz. Romanın yönlendirici karakteri olan Mümin Dede’ye "uzak yakın herkesle çok iyi geçindiği, herkese güler yüz gösterip yardıma koştuğu için" (2016: 16) “Kıvrak Mümin" lâkabını takmışlardır. Tıpkı Tekin'de olduğu gibi bu ad, Mümin Dede karakteriyle bütünleşmiş ve okurun belleğinde yazarın oluşturmak istediği imajı yaratma konusunda yazara destek olmuştur.

Mahlas verme motifi Tekin'de metinlerarası ilişki kurup, anlatımın büyüsünü arttırarak karakterleri masalsı/büyülü kılmaktadır. Bu motif Aytmatov'da ise, Latife Tekin'de olduğu gibi, karakterin kişiliğini okur belleğinde sabitlemek gibi bir işleve sahiptir. Latife Tekin ve Cengiz Aytmatov farklı efsane ve destanlardan da yararlanmışlardır.

\section{Latife Tekin'in Eserlerinde Dede Korkut Hikâyeleri'nin Tezahürü}

Dede Korkut Hikâyeleri Sevgili Arsız Ölüm'de basit bir motif olarak değil, kurguda işlevi olan bir motif olarak karşımıza çıkar.

Dede Korkut Hikâyeleri'nden en bilinenlerinden biri de hiç kuşkusuz “Duha Koca Oğlu Deli Dumrul"dur. Halk arasında kısaca Deli Dumrul olarak anılan bu hikâyede Deli Dumrul'un Azrail ile konuşması ve onunla kavga etmesinin Tekin'in Sevgili Arsız Ölüm'ünde Atiye'de görürüz. Atiye Azrail ile karşılaşır onunla kavga eder ve sonra her işinin yarım kaldığını söyleyerek yalvarmaya başlar. Azrail ise, "kocasının yolunu gözlediği ve beş çocuğunu tek başına doğurup tek başına büyüttüğü için, Atiye'nin isteğini geri çevir[mez]" ve “ona yarım kalan işlerini bitirecek kadar ömür bağış[lar]. (1985: 152-153)

Bu kullanım Atiye'nin roman içindeki gelgitli, netameli yaşantısının bir simgesi gibidir. Özünde bütün bu kullanımlar Tekin'in romanlarında geleneksel anlatı formunun modern roman tekniği/estetiğiyle birleşmesi sonucu ortaya çıkmıştır.

\section{Manas ve Diğger Efsanelerin Aytmatov'da Tezahürü}

Manas Destanı, Kırgız Türkleri için büyük bir öneme sahiptir. Gelenek ve görenekleri, inanışları, manevi değerleri ve diğer milletlerle olan ilişkileri hakkında bilgi veren önemli bir eserdir.

Kırgız yazarların şanslı oldukları noktaların başında Kırgız sözlü edebiyatı gelmektedir. Kırgız sözlü edebiyatının ne denli güçlü olduğunu Manas'tan yola çıkarak kestirmek mümkündür. Cengiz Aytmatov da bu geleneği romanlarında kullanır.

Manas kullanımının en somut örneğine Aytmatov'un "Yıldırım Sesli Manasçı” adlı hikâyesinde rastlarız. Hikâyenin metinlerarası bağlantılarını kuran asıl unsur ise Manas Destanı'ndan alınan bölümlerdir. Bu uzun hikâyenin ana karakteri olan Eleman'ın bir ihanet sonucu gözleri oyularak öldürülür. 
“Eleman öldürülmesi ile birlikte onun biyolojik varlığı sonlandırılmıştır fakat o, fenomonolojik bir varlık olarak 'ses'le var olmuştur. Bu nedenle Yıldırım Sesli'dir. Çarpan, irkilten ve uyaran bir sese dönüşür, Manas Destanı'ndan bölümler okur. Kırgızların atalar kültü ile tinsel iletişime geçme sesi olan Manas, gökte yankılanan Nayman Ana Efsanesindeki Dönenbay kuşunun Colaman'a söylediği 'Adın hatırla!' sesi gibi, Kırgız toplumunu anımsama uzamlarına çağıran sestir. O, ulaşamadığımız ama yine de etkisini hissettiğimiz dağların kuytularında bir "yankı", okurun imgeleminde bir 'ses', ulusun belleğinde 'ölmezlik ruhu' olarak kalır."(Durmuş 2009: 210)

Cengiz Aytmatov Manas'ı bir izleğe yaymaktan çok, o izleğin anlaşılmasını sağlayacak ve olay halkasında etkili olacak biçimde kullanır. Eleman'ın "yıldırım sesli" olması ve halkının bilincini açan, onları atalarıyla, manevi değerleriyle buluşturan sesi "Yıldırım Sesli Manasçı" adlı hikâye için önemli bir özelliktir.

Bu yaklaşıma bir başka örnek ise "Mankurtluk" konusudur. Asimile olma, özünden kopma, benliğin değişimi, hafızasının yitimini Cengiz Aytmatov halk arasında anlatılan Nayman Ana Efsanesi yeniden yazar. Bu kullanım, Gün Olur Asra Bedel için oldukça önemli bir işleve sahiptir. Sabitcan karakterinin varlığındaki payının yanı sıra asimile olan, yabancı hayranlığı duyan Kırgızlar için de modern bir eleştiri saçağıdır.

Aytmatov, Nayman Ana Efsanesini yeniden yazarak o dönemin içyapısını ve dinamiğini eleştirel bir şekilde tanımlar. Bu, o kadar gizil bir eleştiridir ki, Sovyetlerin edebiyata yaptığı müdahalelerden sıyrılıp baskıya gider kitap. Cengiz Aytmatov yaptığı şeyin bilincindeydi ve onun ne yaptığ anlaşılmıştır.

Mankurtluk izleğinin gizil bir şekilde işlendiğ bir diğer eser ise Dişi Kurdun Rüyaları'dır. Romanın başat karakterlerinden birisidir kurt. Neden kurdun kullanıldı̆̆ı sorusu bir başka Kırgız yazarın hikâyesiyle daha da açığa çıkar:

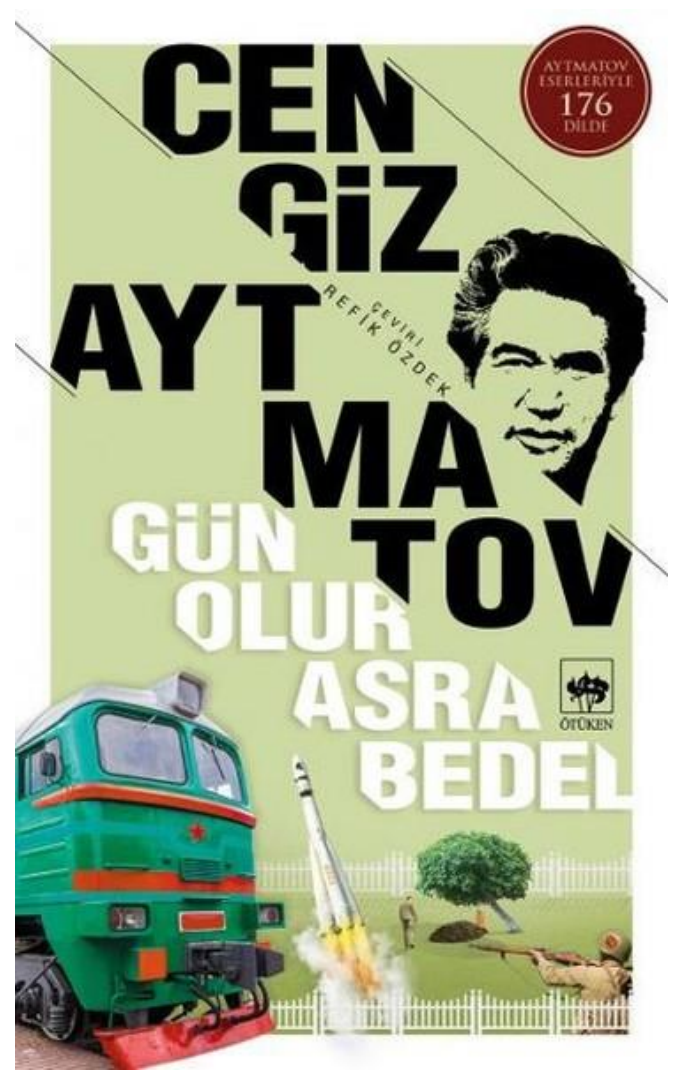

“Ne yapacaksın bunları? diye sordu yavrulara acıyan gönlünden gelen bir ses. 'Onları köpeğe dönüştüreceğim' diye karşılık verdi başka, soğuk bir ses. 'Kurt hiçbir zaman köpek olamaz ama' diye karşılık verdi gönül sesi. Soğuk ses bir kahkaha patlatıp 'Burada yaşayacaklar, masamın artıklarıyla beslenecekler; 
annelerinin, sütüyle verdiği kurtluk duygusunu kaybedecekler. Böylece köpeğe dönüşecekler."(Söylemez vd. 2009: 102)

Tölögön Kasımbekov'un “Bozkurt” hikâyesinden alınan bu pasajda kurtların “köpeğe dönüştürülme" düşüncesi bir asimile etme eğilimidir. Türk mitolojisindeki kurt motifinin kaynağı, kurtların boyun eğmeyen, asi ve özüne olan sebatından gelmektedir. İsmail Turan Kallimci ise "Bozkurt" hikâyesi için yaptığı çözümlemede bu alegoriyi şöyle dile getirir: "Hikâyede köpekleştirmek ile sembolize edilen kavram, Kırgızları asimile etmeyi ifade eder. Hikâyenin şahıs kadrosunda bulunan köpek ise asimile olmuş Kırgızları temsil etmektedir. Köpek bilindiği gibi biyolojik olarak kurt türüyle akrabadır. Ama hikâye içinde kurdun 'Ah zavallım! Gök sana güç vermediği için sen insanın verdikleriyle doyuruyorsun karnını. Acınacak haldesin' monoloğu vasıtasıyla verilen düşünce, köpeğin sahibine sadık, ondan korkan ve yaşam için onun eline bakan bir hayvan olarak karşımıza çıkmaktadır. Dolayısıyla köpek hikâye içinde asimile olmuş Kırgıları temsil etmektedir." (2016: 203) İşte bu nedenle Dişi Kurdun Rüyaları'nda başat karakter kurttur. Asimile olmayan, yani Mankurtlaşmayan Kırgız halkını temsil ettiği için.

Tölögön Kasımbekov'un hikâyesinde kurtları kaçırıp, çuvalla evine götüren şahısla Dişi Kurdun Rüyaları'nda Taşçaynar ve Akbar'ın yavrularını çalan Bazarbay, birbirine paralel iki Mankurttur. Aytmatov bu efsaneyi tıpkı Gün Olur Asra Bedel'de olduğu gibi asimile olma(ma) izleği üzerinden işlevselleştirmiş ve üst-dil kullanarak simgeleştirip toplumsal eleştiri yapmıştır.

Bir başka Mankurt ise Beyaz Gemi romanındaki Orozkul'dur. “Çıkarcı, tembel, despot, alkolik ve kendini beğenmiş Orozkul, konumunun verdiği gücü sınırsızca kullanır ve çevresinde terör estirir. [...] Adına yakışır bir biçimde (Orozkul - [O] Rus kulu) adeta Rus kölesi gibi Sovyet ve Rus varlığının ve mutlak iktidarının sadık uygulayıcısıdır o." (Kara 2013: 125) “Beni görmek isteyenler 'Sayın Orozkul Balacanoviç, makamınıza girebilir miyim?' diye izin alırlardı. [...] Evde yalnız Rusça konuşulurdu. Köyde konuşulan kaba kelimelerle beyinlerini doldurmak ne işe yarar?" (2016: 73)

Orozkul'un bilincinden geçenlerin iç monolog tekniğiyle sunulduğu bölümden alınan pasajda okur Orozkul'un bilincinden geçenleri duyar. Bunlar tamamen Rus hayranlığı ve kendi değerlerinden kopma, dahası, bu değerleri hakir görme üzerinedir. Rus soyadı olması, çocuklarını şehirde okutup, şehirli bir kadınla evlenmeyi düşlemesi ve en fenası da Rus dilini övmesi onun artık bir Kırgız değil de Mankurt olduğunun en net argümanıdır. Peki, Orozkul'un sahip olduğu bu bilincin roman içindeki işlevi nedir? Orozkul bu bilince sahip olmasaydı, geleneklerine bağlı bir Kırgız olsaydı eğer, Mümin Dede'yi hırpalamaz, çocuk sahibi olabilir (romanda bu sorunun temel nedeni Berkey Teyze gösterilse de, Orozkul'un bu bilinçte bir karakter olması da oldukça etkilidir) ve Maral Ana'yı vurdurmazdı; dolayısıyla 
romanın sonu şu anki hâlini alamazdı. Bu nedenle işlev olarak hem Orozkul'u karşıt güç olarak karşımıza çıkarmış hem de romanın temel izleğinin verilmesinde kilit rol oynamıştır. Dolayısıyla Aytmatov'un hemen her romanında ağır ya da hafif olarak Mankurt eleştirisi vardır. Kimi zaman bu Mankurt eleştirisi işlevleşirken kimi zaman sadece bir motif olarak kalır.

\section{Sonuç}

Cengiz Aytmatov ve Latife Tekin, romanlarında geleneksel anlatma formlarını modern tekniklerle birleştirip anlatımda zirveye ulaşmışlardır. Her iki yazar da geleneği roman içinde eritip, onu, romanın çarkında bir dişli yaparak, kurdukları sistemin ilerlemesinde etkin kılmışlardır. Bu sistemin ilerlemesinde etkili olan metinlerarasılık tekniği bu iki yazarın eserlerinde açıkça görülmektedir. Çalışmamızda bu postmodern anlatma formu ile geleneğin kurgu içerisinde işlevleşmesini gördük.

Buradan hareketle, geleneğin hiçbir zaman kaybolmayacak ölçüde büyük bir yazınsal değeri olduğunu, çağlar geçse, edebiyat kendine yeni kalıplar bulsa da vazgeçilemeyen, kıymetli bir hareket noktası olduğunu anlıyoruz. Ayrıca iki farklı coğrafyada, hemen hemen aynı dönemde kalem oynatmış yazarların değer oluşturma ve değerleri gelecek nesillere aktarma hususunda üslup birlikteliğini de dikkat çekicidir.

\section{Kaynakça}

Aktulum, Kubilay (2000). Metinlerarası İlişkiler. İstanbul: Öteki Yayınevi.

Aktulum, Kubilay (2011). Metinlerarasılık/Göstergelerarasılık. Ankara: Kanguru Yayınları.

Arık, Şahmuran (2007). “Latife Tekin'in Romanlarında Gelenek”. Atatürk Kültür, Dil ve Tarih Yüksek Kurumu, ICANAS 38, Uluslararası Asya ve Kuzey Afrika Çalışmaları Kongresi, Ankara.

Arslan, Fatih (1998). “Aytmatov'un Estetiğinin Geçmişe Dönük Ütopik / Postromantik Yüzü". Doğumunun 70. Yıl Dönümünde Cengiz Aytmatov Uluslararası Bilgi Şöleni Bildirileri (8-10 Aralık) s. 45-50.

Aytmatov, Cengiz (1995). Yıldırım Sesli Manasçı-Yüzyüze-Deniz Kıyısında Koşan Ala Köpek (Hikâyeler). çev. Refik Özdek, İstanbul: Ötüken Yayınları.

Aytmatov, Cengiz (2013). Kassandra Damgası. çev. Ahmet Pirverdioğlu. Ankara: Elips Kitap. Aytmatov, Cengiz (2016). Beyaz Gemi. çev. Refik Özdek, İstanbul: Ötüken Yayınları. Aytmatov, Cengiz (2016). Dişi Kurdun Rüyaları. çev. Refik Özdek, İstanbul: Ötüken Yayınları. Aytmatov, Cengiz (2016). Gün Olur Asra Bedel. çev. Refik Özdek, İstanbul: Ötüken Yayınları.. Balık, Macit (2011). Latife Tekin'in Romancılı̆̆ı. Doktora Tezi. Ankara: Ankara Üniversitesi. 
Durmuş, Mithat (2009). Cengiz Aytmatov (Prestij Kitabı). Ankara: T.C. Kültür ve Turizm Bakanlığ1 Yayınları.

Ecevit, Yıldız (2013). Kurmaca Bir Dünyadan. İstanbul: İletişim Yayınları.

Kallimci, İsmail Turan (2016). “Atasözleri ile Hikâye Yazmak: Tölögön Kasımbekov'un Bozkurt adlı Hikâyesinin İncelenmesi". The Journal of Academic Socail Science Studies Winter III.

Kara, Halim (2013). "Sömürgeciyi" Tahayyül Etmek: Cengiz Aytmatov'un Kurmacasında Rusların Edebî Temsili". İstanbul Üniversitesi Edebiyat Fakültesi Türk Dili ve Edebiyatı Dergisi, 45 (45). Retrieved from http://dergipark.gov.tr/iutded/issue/17073/178567. 113138.

Moran, Berna (2014). Türk Romanına Eleştirel Bir Bakış - II. İstanbul: İletişim Yayınları.

Moran, Berna (2015). Türk Romanına Eleştirel Bir Bakış-III. İstanbul: İletişim Yayınları.

Orhan Söylemez ve Halit Aşlar (2009). Kırgız Hikâyeleri Antolojisi. Erzurum: Salkımsöğüt Yayınevi

Ögel, Bahaeddin (1993). Türk Mitolojisi-I. , Ankara: Türk Tarih Kurumu Basımevi.

Ögel, Bahaeddin (1995). Türk Mitolojisi-II. Ankara: Türk Tarih Kurumu Basımevi.

Öktemgil, T. C. (2003). Latife Tekin'in Yapıtlarında Büyülü Gerçekçilik. Yayımlanmamış Yüksek Lisans Tezi, Ankara: Bilkent Üniversitesi.

Özcan Bayrak, Tahsin Yaprak (2003). “Cengiz Aytmatov'un Yazarlık Üslubunun ve 'Yıldırım Sesli Manasçı' Hikâyesinde İncelenmesi”. International Jurnal of Social Science. Volume 6 Issue 4, p. 159-177, April 1.

Tekin, Latife (1985). Sevgili Arsız Ölüm. İstanbul: Adam Yayınları.

Toptaş, Hasan Ali (2015). Başlarken Yalnızsın, Bitirdiğinde Daha da Yalnız. İstanbul: İletişim Yayınları.

Türkmenoğlu, Sevgi (2015). “Latife Tekin'in Sevgili Arsız Romanında Büyülü Gerçeklik”. A. Ü. Türkiyat Araştırmaları Enstitüsü Dergisi, S: 54, s. 417-426. 